\title{
PENGARUH PENGGUNAAN LIMBAH PLASTIK POL YPROPYLENE (PP) SEBAGAI CAMPURAN AGREGAT KASAR TERHADAP KUAT TEKAN DAN TARIK PADA BETON FC' 25 MPA
}

\author{
(Effect of The Use of Polypropylene (Pp) Plastic Waste as a Coarse Aggregate Mixture Of \\ Compressive Strength and Tensile Strength of Concrete Fc'25 Mpa)
}

\author{
Angga Pirman Firdaus ${ }^{1}$, Jonbi ${ }^{1}$ \\ ${ }^{1}$ Program Studi Teknik Sipil Universitas Pancasila \\ E-mail:anggapirman@gmail.com
}

\begin{abstract}
ABSTRAK
Indonesia berada di peringkat kedua di dunia penghasil sampah plastik terbesar setelah Cina. Setiap tahunnya Indonesia mampu menyumbang sampah hingga 187,2 juta ton sampah plastik, Sedangkan Cina mencapai 262,9 juta ton sampah plastik. Berdasarkan pada data tersebut, salah satu cara untuk memanfaatkan limbah plastik dengan menggunakan limbah plastik sebagai bahan campuran pada beton, dimana plastik yang digunakan adalah plastik polypropylene (PP) dengan prosentase yang berbeda pada campuran beton, pengujian yang dilakukan meliputi pengujian kuat tekan dan tarik pada beton. Hasil pengujian kuat tekan beton dengan campuran limbah plastik polypropylene (PP) 5\%, 10\% dan 15\% pada umur 28 dalam campuran agregat kasar mengalami penurunan sebesar $5,15 \%, 6,89 \%$ dan $13,53 \%$. Sedangkan untuk hasil pengujian kuat tarik beton dengan campuran limbah plastik polypropylene (PP) 5\%, 10\% dan 15\% pada umur 28 dalam campuran agregat kasar mengalami penurunan sebesar $17,61 \%, 24,13 \%$ dan $23,24 \%$.
\end{abstract}

Kata Kunci: Limbah Plastik, Polypropylene (PP), Kuat Tekan, Kuat Tarik

\begin{abstract}
Indonesia ranks second in the world's largest plastic waste producer after China. Each year, Indonesia can contribute up to 187.2 million tons of plastic waste, while China reaches 262.9 million tons of plastic waste. Based on the data, one way to utilize plastic waste by using plastic waste as a mixture of concrete, where the plastic used is polypropylene (PP) plastic with different percentage of concrete mixture, the test includes compressive strength test and tensile concrete. The results of concrete compressive strength testing with polypropylene (PP) plastic waste mixture of 5\%, 10\% and 15\% at age 28 in aggregate aggregate mixture decreased by $5.15 \%, 6.89 \%$ and $13.53 \%$. As for the result of concrete tensile strength test with polypropylene (PP) plastic waste mixture of $5 \%, 10 \%$ and $15 \%$ at age 28 in crude aggregate mixture decreased 17,61\%,24,13\% dan 23,24\%.
\end{abstract}

Keywords: Plastic Waste, Polypropylene (PP), strength test, tensile test 


\section{PENDAHULUAN}

Indonesia berada di peringkat kedua dunia penghasil sampah plastik terbesar setelah Cina. Setiap tahunnya Indonesia mampu menyumbang sampah hingga 187,2 juta ton. Sedangkan Cina mencapai 262,9 juta ton, berada di urutan ketiga adalah Filipina yang menghasilkan sampah plastik mencapai 83,4 juta ton, di ikuti oleh Vietnam yang mencapai 55,9 juta ton dan Sri Lanka yang mencapai 14,6 juta ton per tahun (Jambeck, et al., 2015).

Menurut Dinas Kebersihan Pemerintah Provinsi DKI Jakarta tahun 2011, volume sampah di Jakarta Pusat sebesar $5.368 \mathrm{~m}^{3} /$ hari, Jakarta Utara sebesar 4.313 $\mathrm{m}^{3} /$ hari, Jakarta Barat sebesar $5.500 \mathrm{~m}^{3} /$ hari, Jakarta Selatan sebesar $5.443 \mathrm{~m}^{3} /$ hari dan Jakarta Timur sebesar $6.321 \mathrm{~m}^{3} /$ hari. Dimana data komposisi dan karakteristik sampah plastik sebesar $14 \%$ dan untuk jenis sampah plastik Polypropylene (PP) sebesar $2.03 \%$ dari total sampah plastik yang ada.

Plastik memiliki banyak kelebihan dibandingkan bahan lainnya. Secara umum, plastik memiliki densitas yang rendah, bersifat isolasi terhadap listrik, kekuatan mekanik yang bervariasi, ketahanan suhu terbatas, serta ketahanan bahan kimia yang bervariasi. Selain itu, plastik juga ringan, mudah dalam perancangan dan biaya pembuatannya murah.

Dibalik kelebihannnya, limbah plastik menimbulkan masalah bagi lingkungan. Penyebabnya tak lain sifat plastik yang tidak dapat diuraikan dalam tanah. Untuk mengatasinya, para pakar lingkungan dan ilmuwan dari berbagai disiplin ilmu telah melakukan berbagai penelitian dan tindakan. Salah satunya dengan cara mendaur ulang limbah plastik. Namun cara ini tidaklah terlalu efektif. Hanya sekitar $4 \%$ yang dapat didaur ulang, sisanya menggunung di tempat penampungan sampah (Pamudji, et al., 2008).

Penambahan cacahan gelas plastik polypropylene (PP) terhadap berat semen kedalam campuran beton akan meningkatkan kuat tarik belah beton. Kenaikan kuat tarik optimum terjadi pada beton dengan persentase cacagan gelas plastik $0,50 \%$, yaitu sebesar $24,264 \mathrm{~kg} / \mathrm{cm}^{2}$ atau kenaikan sebesar $21,789 \%$. untuk persentase cacahan gelas plastik $0,75 \%, 1,00 \%$ dan $1,25 \%$, beton mulai mengalami penurunan kuat tarik pada masing-masing sebesar $23,073 \mathrm{~kg} / \mathrm{cm}^{2}, 22,279$ $\mathrm{kg} / \mathrm{cm}^{2}$ dan $21,981 \mathrm{~kg} / \mathrm{cm}^{2}$. (Ridwan, et al., 2014)

Penggantian sebagian pasir dengan bahan sampah plastik dari limbah Polypropylene (PP) dimana digunakan untuk mengganti $20 \%, 40 \%$ dan $60 \%$ pasir sungai alami dalam campuran beton dan diuji setelah 28 Hari untuk kekuatan tekan, kuat tarik, kekuatan lentur dan densitas beton yang dimodifikasi. Hasil dari percobaan tersebut,penggantian sebagian bahan limbah plastik dapat dilakukan sampai batas 20\% sampai $40 \%$, dimana dengan campuran limbah plastik sebagai agregat halus pada beton dengan persentase $0 \%$ di dapat nilai kuat tekan sebesar $26.47 \mathrm{MPa}, 20 \%$ limbah plastik di dapat nilai kuat tekan $34.53 \mathrm{MPa}$ dan mengalami penurunan nilai kuat tekan pada campuran $40 \%$ limbah plastik sebesar $32.3 \mathrm{MPa}$ dan $60 \%$ campuran limbah plastik sebesar 25.83 MPa. Dimana Penelitian ini membuktikan bahwa penggantian pasir alami di beton dimungkinkan dengan limba sampah plastik sebagai penggantinya (Charudatta, et al., 2017).

Pemanfaatan sampah menjadi material yang berguna sangat penting dan perlu untuk dilakukan, termasuk menggunakan sampah plastik sebagai campuran agregat beton, dimana bahan dari sampah plastik mudah diperoleh dan selama ini belum termanfaatkan secara optimal. Penelitian ini akan menggunakan agregat yang berasal dari sampah plastik jenis polypropylene (PP). Jenis plastik ini merupakan salah satu jenis plastik polietilena termoplastik yang banyak digunakan dalam kehidupan sehari - hari.

Maksud dari penelitian adalah untuk mengetahui karakteristik beton normal dengan campuran limbah plastik jenis Polypropylene (PP) sebagai bahan pembanding digunakan beton normal dengan mutu yang sama. Dengan tujuan untuk menganalisa pengaruh penggunaan limbah plastik jenis Polypropylene (PP) sebagai campuran agregat kasar pada campuran beton normal Fc' $25 \mathrm{MPa}$ terhadap kuat tekan dan kuat tarik pada beton. Dimana manfaat yang diharapkan dari penelitian ini adalah diperolehnya suatu gambaran tentang kuat tarik dan kuat tekan pada beton normal dengan cara membandingkan beton normal yang menggunakan bahan tambah berupa limbah plastik jenis polypropylene (PP) sebagai campuran agregat kasar dengan yang tidak menggunakan bahan tambah dan untuk memanfaatkan limbah plastik jenis Polypropylene (PP) agar dapat dijadikan alternatif sebagai agregat kasar pada campuran beton.

Plastik Polypropylene (PP) merupakan salah satu jenis plastik Thermoplastik, dimana jenis plastik ini dapat dikembangkan sebagai material dalam bangunan, karena sifatnya yang mudah didaur ulang

Adapun proses pengolahan limbah plastik Polypropylene menjadi biji plastik yang digunakan sebagai campuran agregat kasar pada campuran beton seperti pada Gambar 1. 


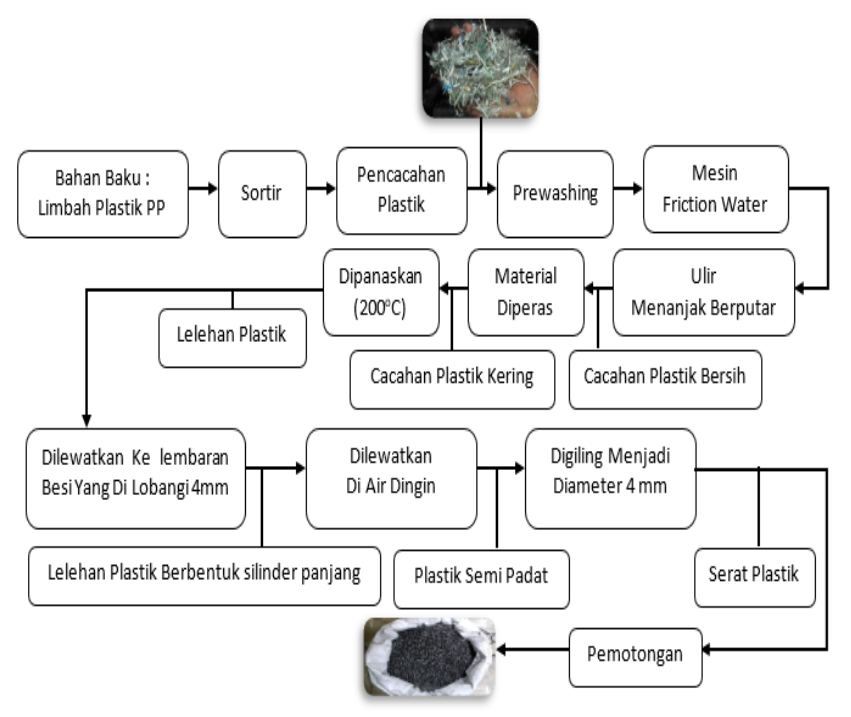

Gambar 1.Proses pengolahan limbah plastik Polypropylene (PP)

Sumber: Analisa Penulis,2017

Dari proses pengolahan limbah plastik polypropylene (PP) bahan baku berupa karung di dapat hasil pengolahan berupa biji plastik sekitar $30-35 \%$ dari $100 \%$ bahan baku yang di proses, hasil dari proses pengolahan limbah plastik polypropylene bahan baku karung berupa biji plastik.

Karakteristik dari plastik polypropylene memiliki kuat tarik (Tensile Strenght) sebesar 35,8 MPa, ketahanan pukul (Impact Strength) sebesar $43 \mathrm{~J} / \mathrm{m}$, specific gravity rendah dibandingkan dengan jenis plastik lain yaitu antara 0,85-0,90 dan ketahanan terhadap terhadap bahan kimia yang tingi dan titik leleh yang cukup tinggi $200-300{ }^{\circ} \mathrm{C}$ (Felixon, 2011).

\section{METODE}

Metode penelitian dilakukan menggunakan dua metode yaitu metode pengumpulan data melalui studi pustaka atau studi dokumenter dan metode observasi dengan cara melakukan pengujian langsung di laboratorium sesuai Standar Nasional Indonesia (SNI).

Metode penelitian yang digunakan pada penelitian ini sesuai dengan diagram alir metode penelitian seperti pada Gambar 2.

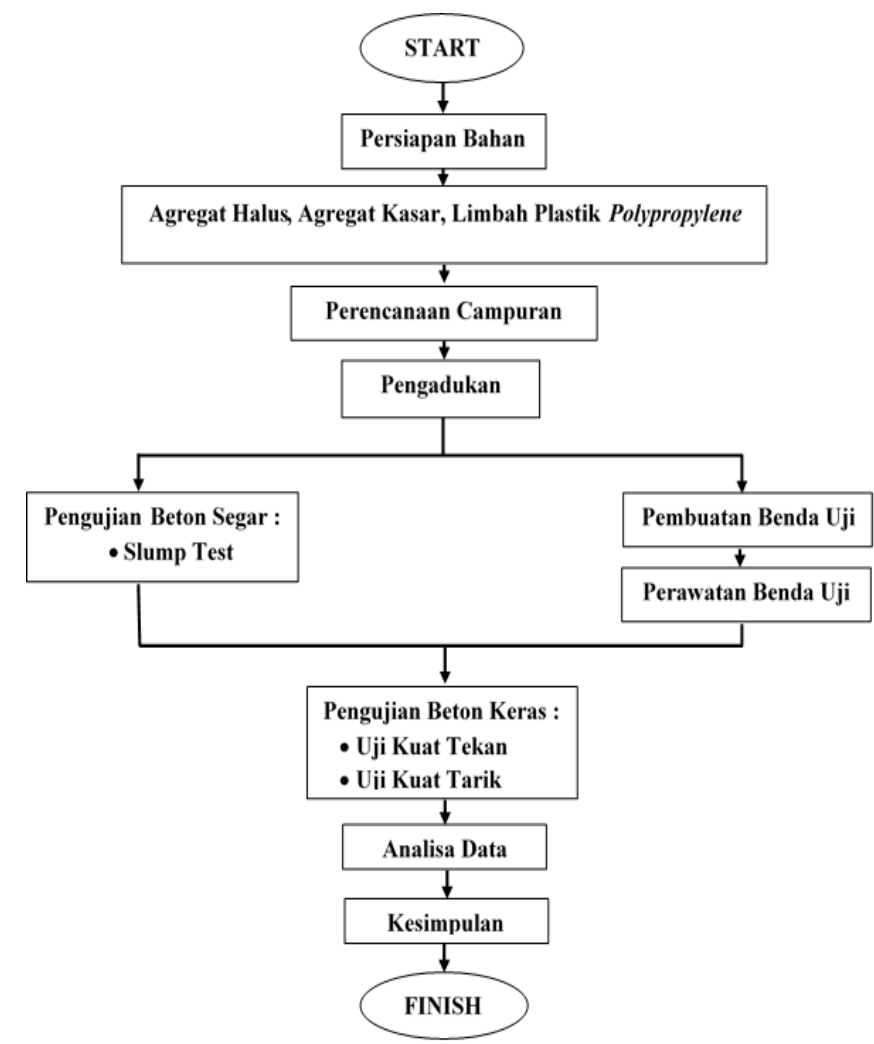

Gambar 2. Diagram Alir Metode Penelitian

Sampel yang akan dibuat dalam penelitian adalah beton normal dengan Fc' $25 \mathrm{MPa}$. Dimana campuran beton normal dengan perbandingan komposisi agregat kasar $100 \%$ dan limbah plastik 0\% untuk sampel penelitian tersebut memiliki kode BN. Agregat kasar 95\% dan limbah plastik $5 \%$ untuk sampel penelitian tersebut memiliki kode BPL 1. Agregat kasar $90 \%$ dan limbah plastik $10 \%$ untuk sampel penelitian tersebut memiliki kode BPL 2. Agregat kasar $85 \%$ dan limbah plastik $15 \%$ untuk sampel penelitian tersebut memiliki kode BPL 3. Komposisi yang berbeda-beda pada setiap sampel penelitian bertujuan untuk mengetahui proporsi campuran limbah plastik sebagai campuran agregat kasar yang efektif terhadap campuran bahan beton Fc' $25 \mathrm{MPa}$.

Tabel 1. Prosentase campuran beton yang akan di buat dalam penelitian

\begin{tabular}{|c|c|c|c|c|c|}
\hline \multicolumn{7}{|c|}{ Komposisi Bahan } \\
\hline Kode & $\begin{array}{c}\text { Semen } \\
(\mathrm{kg})\end{array}$ & $\begin{array}{c}\text { Pasir } \\
(\mathrm{kg})\end{array}$ & $\begin{array}{c}\text { Kerikil } \\
(\mathrm{kg})\end{array}$ & $\begin{array}{c}\text { Plastik } \\
(\mathrm{kg})\end{array}$ & $\begin{array}{c}\text { Air } \\
(\mathrm{Itr})\end{array}$ \\
\hline BN & $100 \%$ & $100 \%$ & $100 \%$ & $0 \%$ & $100 \%$ \\
\hline BP 1 & $100 \%$ & $100 \%$ & $95 \%$ & $5 \%$ & $100 \%$ \\
\hline BP 2 & $100 \%$ & $100 \%$ & $90 \%$ & $10 \%$ & $100 \%$ \\
\hline BP 3 & $100 \%$ & $100 \%$ & $85 \%$ & $15 \%$ & $100 \%$ \\
\hline
\end{tabular}

Sumber : Analisa Penulis, 2017

Masing - masing variasi dibuat 3 buah benda uji berbentuk silinder dengan ukuran $\varnothing 10 \mathrm{~cm}$ dan tinggi 
$20 \mathrm{~cm}$ untuk uji tekan dan tarik pada beton yang akan dilakukan pengujian pada umur 3, 7 dan 28 hari di Laboratorium beton jurusan Sipil Fakultas Teknik Universitas Pancasila. Adapun tahapan penelitiannya sebagai berikut:

\section{Persiapan Bahan}

Pada tahap ini seluruh bahan yang dibutuhkan dipersiapkan terlebih dahulu, diantaranya semen, air, agregat yaitu butiran mineral alami yang berfungsi sebagai bahan pengisi beton berupa pasir dan kerikil serta limbah plastik polypropylene (PP) sebagai campuran agregat kasar. Dengan jumlah bahan yang digunakan sesuai dengan mix design yang dibuat dalam perencanaan campuran beton. Bahan limbah plastik yang digunakan sebagai campuran adalah limbah plastik berupa biji plastik polypropylene (PP).

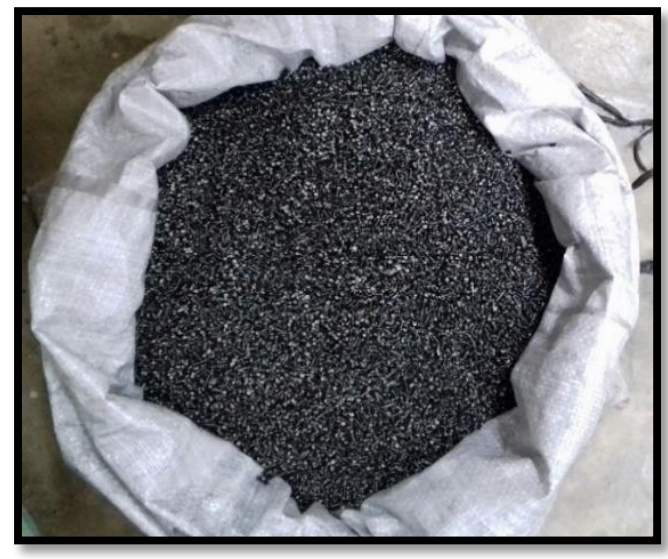

Gambar 2. Biji plastik polypropylene (PP)

Sumber: Dokumentasi Penulis,2017

\section{Perencanaan Campuran}

Pada tahahap ini, dilakukan perencanaan campuran beton dengan kuat tekan rencana $\mathrm{Fc}^{\prime} 25 \mathrm{MPa}$ menggunakan standar perencanaan Standar Nasional Indonesia (SNI 03-2834-2000, Tata Cara Pembuatan Rencana Campuran Beton Normal).

Tabel 2. Komposisi bahan campuran beton 9 sampel (Silinder : $\varnothing=10 \mathrm{~cm}$ dan $\mathrm{t}=20 \mathrm{~cm}$ )

\begin{tabular}{|c|c|c|c|c|c|}
\hline \multicolumn{7}{|c|}{ Komposisi Bahan } \\
\hline Kode & $\begin{array}{c}\text { Semen } \\
(\mathrm{kg})\end{array}$ & $\begin{array}{c}\text { Pasir } \\
(\mathrm{kg})\end{array}$ & $\begin{array}{c}\text { Kerikil } \\
(\mathrm{kg})\end{array}$ & $\begin{array}{c}\text { Plastik } \\
(\mathrm{kg})\end{array}$ & $\begin{array}{c}\text { Air } \\
(\mathrm{Itr})\end{array}$ \\
\hline BN & 8,30 & 10,79 & 20,04 & 0 & 3,30 \\
\hline BP 1 & 8,30 & 10,79 & 18,62 & 1,00 & 3,30 \\
\hline BP 2 & 8,30 & 10,79 & 17,64 & 2,00 & 3,30 \\
\hline BP 3 & 8,30 & 10,79 & 16,66 & 3,00 & 3,30 \\
\hline
\end{tabular}

Sumber : Perhitungan Penulis, 2017

Jumlah sample yang akan di uji sebanyak 36 buah untuk uji tekan, 36 buah untuk uji tarik, jumlah benda uji keseluruhan sebanyak 72 buah dalam kurun waktu pengujian 3,7 , dan 28 hari.

\section{Pembuatan Benda Uji}

Pada tahap ini bahan yang telah dipersiapkan, diaduk dengan menggunakan mesin pengaduk. Langkah pertama kerikil dan pasir dimasukan kedalam mesin pengaduk kemudian semen dimasukkan. Setelah bahan tersebut tercampur merata, masukan air sedikit demi sedikit sambil diaduk. Kemudian limbah plastik polypropylene (PP) dimasukkan pada adukan tersebut secara merata dan terus diaduk hingga semua bahan tercampur. Langkah terakhir yaitu mencetak adukan dalam bentuk silinder dengan ukuran $\varnothing 10 \mathrm{~cm}$ dan tinggi $20 \mathrm{~cm}$.

\section{Pengujian Beton Segar}

Pada tahap ini dilakukan pengujian slump tes, Slump test adalah pengujian paling sederhana dan yang paling sering digunakan. Karenanya kelecakan beton segar sering diidentikkan dengan slumpnya. Kelecakan beton atau workability adalah kemudahan suatu campuran beton segar untuk dikerjakan dan dipadatkan. kelecakan memegang peran penting dalam kualitas beton, kini kelecakan secara praktis di uji baik di lapangan maupun di laboratorium. Slump tes berguna untuk mengecek adanya perubahan dari kadar air, bila material dan gradasi agregat adalah seragam. Bila jumlah air adalah konstan dan kadar lengas agregat juga konstan maka slump test berguna untuk menunjukan adanya perbedaan pada gradasi. Kelemahan uji slump adalah tidak dapat mengukur kelecakan campuran beton yang kaku (Nugraha,2007).

\section{Perawatan}

Pada tahap ini dilakukan perawatan terhadap benda uji yang telah dibuat pada tahap sebelumnya. Perawatan ini dilakukan dengan cara merendam benda uji ke dalam air pada bak perendaman dihari kedua selama umur rencana pengujian yaitu 3,7 dan 28 hari. Perawatan beton merupakan suatu tahap akhir pekerjaan pembetonan, yaitu menjaga agar permukaan beton segar selalu lembab, sejak dipadatkan sampai proses hidrasi cukup sempurna (kira- kira selama 28 hari). Kelembaban permukaan beton itu harus dijaga agar air di dalam beton segar tidak keluar. Hal ini untuk menjamin proses hidrasi semen (reaksi semen dan air) berlangsung dengan sempurna. Bila hal ini tidak dilakukan, maka oleh udara panas akan terjadi proses penguapan air dari permukaan beton segar, sehingga air dari dalam beton segar mengalir keluar, dan beton segar kekurangan air untuk hidrasi, sehingga timbul retak-retak pada permukaan betonya (Tjokrodimuljo, 2007).

\section{Pengujian Beton Keras}

Pada tahap ini dilakukan pengujian kuat tekandan tarik pada beton pada umur beton 3,7 dan 28 hari. 


\section{- Kuat Tekan}

Kuat tekan beton adalah besarnya beban persatuan luas yang menyebabkan benda uji beton hancur bila dibebani dengan gaya tertentu yang dihasilkan oleh mesin uji tekan. Kuat tekan beton merupakan gambaran mutu beton, karena biasanya kenaikan kuat tekan beton akan diikuti oleh perbaikan sifat beton yang lainnya. Benda uji yang digunakan dalam pengujian ini adalah silinder dengan ukuran $\varnothing 10 \mathrm{~cm}$ dan tinggi $20 \mathrm{~cm}$ sebanyak 3 buah untuk setiap variasinya. Pengujian ini bertujuan untuk mengetahui kemampuan beton dengan campuran limbah plastik polypropylene (PP) dalam menerima beban. Pengujian dilakukan pada umur beton 3, 7 dan 28 hari.

- Kuat Tarik

Kuat tarik belah benda uji silinder beton adalah nilai kuat tarik tidak langsung dari benda uji beton berbentuk silinder yang diperoleh dari pembebanan benda uji tersebut yang diletakkan mendatar sejajar dengan permukaan meja penekan mesin uji tekan. Kuat tarik beton biasanya $8 \%-15 \%$ dari kuat tekan beton, kekuatan tarik adalah suatu sifat yang penting yang mempengaruhi perambatan dan ukuran dari retak didalam struktur. Kekuatan tarik biasanya ditentukan dengan percobaan pembebanan silinder, dimana silinder yang ukurannya sama dengan benda uji dalam percobaan kuat tekan diletakkan pada sisinya di atas mesin uji dan beban tekan $\mathrm{P}$ dikerjakan secara merata dalam arah diameter disepanjang benda uji (Pane, et al., 2015)

Benda uji yang digunakan dalam pengujian ini adalah silinder dengan ukuran $\varnothing 10 \mathrm{~cm}$ dan tinggi $20 \mathrm{~cm}$ sebanyak 3 buah untuk setiap variasinya. Pengujian dilakukan pada umur beton 3, 7 dan 28 hari.

\section{PEMBAHASAN DAN HASIL}

Hasil dari Penelitian ini adalah diperolehnya data pengujian pada sampel yang dibuat seperti data uji slump, kuat tekan dan tarik pada beton.

\section{- Slump Tes}

Dari hasil pengujian beton segar didapatkan nilai slump pada masing-masing benda uji.
Tabel 3. Hasil Uji Slump dan pada

\begin{tabular}{|c|c|c|c|}
\hline \multirow{2}{*}{ Kode } & \multicolumn{2}{|c|}{ Tinggi Slump (cm) } & $\begin{array}{c}\text { Slump } \\
\text { Rata - Rata } \\
(\mathrm{cm})\end{array}$ \\
\cline { 2 - 3 } & $\begin{array}{c}\text { Uji Ke-1 } \\
(\mathrm{cm})\end{array}$ & $\begin{array}{c}\text { Uji Ke-2 } \\
(\mathrm{cm})\end{array}$ & 12,5 \\
\hline BN & 12,5 & 12 & 8,5 \\
\hline BPL 1 & 8 & 9 & 6,5 \\
\hline BPL 2 & 7 & 6 & 6 \\
\hline BPL 3 & 6 & 6 & \multicolumn{2}{|c|}{} \\
\hline
\end{tabular}

Rata - Rata Nilai Slump (Cm)

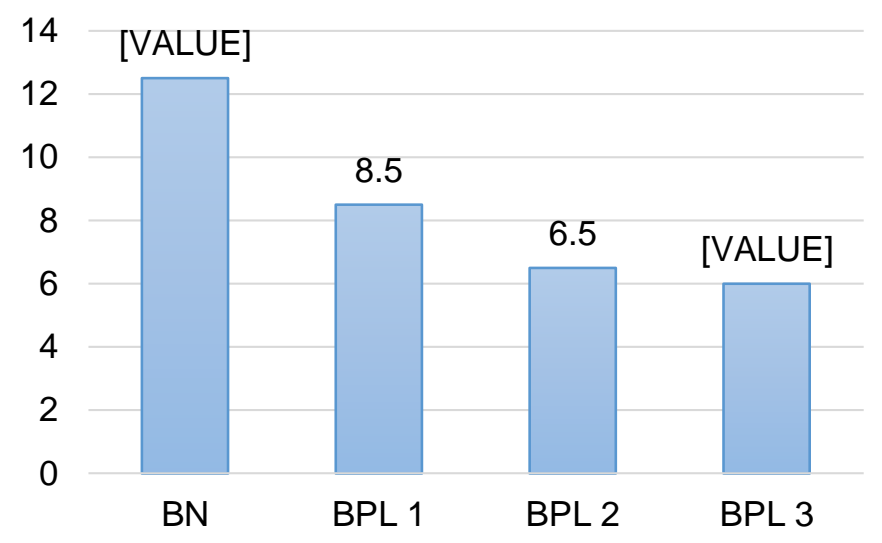

Gambar 3. Grafik Nilai Uji Slump

Sumber: Analisa Penulis (2017)

Berdasarkan data hasil pengujian tersebut, nilai rata rata slump pada campuran beton normal dengan kode BN sebesar $12,5 \mathrm{~cm}$, beton dengan campuran limbah plastik $5 \%$ dengan kode BPL 1 sebesar $8,5 \mathrm{~cm}$, beton dengan campuran limbah plastik $10 \%$ dengan kode BPL 2 sebesar $6,5 \mathrm{~cm}$ dan beton dengan campuran limbah plastik $15 \%$ dengan kode BPL 3 sebesar $6 \mathrm{~cm}$, Besar penurunan nilai slump beton BPL 1, BPL 2 dan BPL 3 dari nilai rata - rata uji slump pada beton normal dapat dilihat pada Gambar 4.

\section{Persentase Penurunan Uji Slump (\%)} $100 \%$

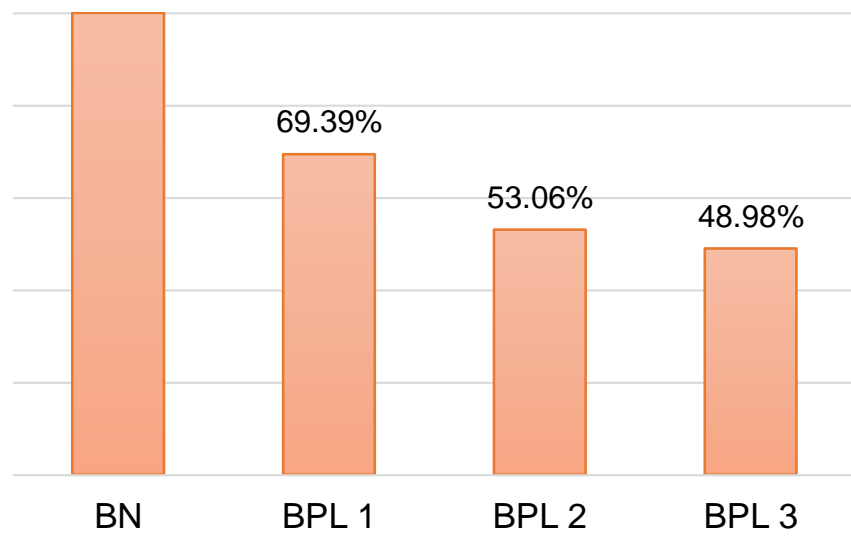

Gambar 4. Grafik Persentase Penurunan Uji Slump Sumber: Analisa Penulis (2017) 
Persentase ini merupakan capaian nilai slump sample beton dalam penelitian ini dengan acuan nilai uji slump pada sampel beton normal.

- Kuat Tekan

Pengujian kuat tekan pada penelitian ini menggunakan benda uji silinder dengan ukuran $\varnothing$ $10 \mathrm{~cm}$ dan tinggi $20 \mathrm{~cm}$, pengujian dilakukan pada umur beton 3 hari, 7 Hari dan 28 hari. Dengan 4 sample komposisi campuran yang berbeda dan pada setiap sample dengan 3 benda uji dalam satu pengujian. Dimana kuat tekan beton rencana sebesar Fc' $25 \mathrm{MPa}$ pada umur beton 28 hari.

Perbandingan kuat tekan pada masing - masing rancang campuran beton dapat dilihat pada Tabel 4. nilai kuat tekan beton gabungan dan perbandingan pada masing-masing umur beton seperti pada umur beton 3 hari, 7 hari dan 28 hari dapat dilihat pada Gambar 5.

Tabel 4. Nilai Rata-Rata Kuat Tekan Beton Gabungan

\begin{tabular}{|c|c|c|c|c|}
\hline \multirow{2}{*}{$\begin{array}{c}\text { Umur } \\
\text { (Hari) }\end{array}$} & \multicolumn{4}{|c|}{ Rata - Rata Kuat Tekan Beton (Mpa) } \\
\cline { 2 - 5 } & Normal & BPL 1 & BPL2 & BPL 3 \\
\hline 3 & 14,31 & 15,65 & 15,01 & 11,34 \\
\hline 7 & 19,94 & 20,36 & 18,58 & 17,24 \\
\hline 28 & 27,44 & 23,71 & 23,28 & 21,62 \\
\hline
\end{tabular}

Sumber: Analisa Penulis,2017

\section{Rata - Rata Perbandingan Kuat Tekan}

(MPa)

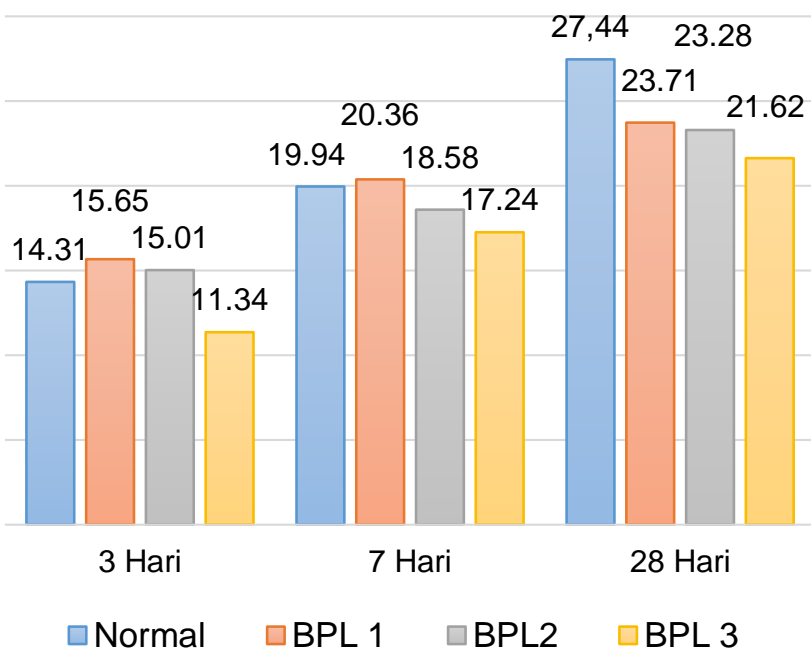

\section{Gambar 5. Grafik Perbandingan Kuat Tekan Pada Masing-Masing Umur Beton}

Sumber: Analisa Penulis (2017)

Nilai kuat tekan pada beton pada umur benda uji 3 hari, kuat tekan beton campuran normal 14,31 MPa. Sedangkan tiga variasi campuran beton lainnya memiliki kuat tekan terbesar adalah BPL 1 dengan nilai kuat tekan sebesar 15,65 MPa dan kuat tekan terbesar kedua adalah BPL 2 dengan nilai kuat tekan sebesar 15,01 MPa dan nilai kuat tekan terendah adalah BPL 3 dengan nilai kuat tekan sebesar 11,34 MPa. Nilai kuat tekan beton pada umur benda uji 7 hari, kuat tekan beton campuran normal 19,94 MPa. Sedangkan tiga variasi campuran beton lainnya memiliki kuat tekan terbesar adalah BPL 1 dengan nilai kuat tekan sebesar 20,36 MPa dan untuk kuat tekan BPL 2 sebesar 18,58 $\mathrm{MPa}$ dan nilai kuat tekan terendah adalah BPL 3 dengan nilai kuat tekan sebesar 17,24 MPa. Nilai kuat tekan beton yang direncanakan pada umur benda uji 28 hari adalah beton dengan nilai kuat tekan Fc' 25 $\mathrm{MPa}$, kuat tekan beton campuran normal memiliki kuat tekan sebesar 27,44 MPa kuat tekan beton normal pada umur beton 28 hari sudah sesuai dengan kuat tekan beton rencana. Untuk tiga variasi campuran beton lainnya memiliki kuat tekan lebih kecil dibandingkan dengan beton normal dimana BPL 1 dengan nilai kuat tekan sebesar $23,71 \mathrm{MPa}$ dan untuk kuat tekan BPL 2 sebesar 23,28 MPa dan nilai kuat tekan terendah adalah BPL 3 dengan nilai kuat tekan sebesar 21,62 MPa. Untuk beton dengan campuran limbah plastik memiliki kekuatan terhadap tekan lebih tinggi pada komposisi campuran limbah sebanyak 5\% terhadap berat agregat kasar, namun pada saat campuran sebesar $10 \%$ dan $15 \%$ limbah plastik, kekuatan tekan pada beton menurun dan lebih kecil.

Besar persentase penurunan rata - rata uji kuat tekan beton BPL 1, BPL 2 dan BPL 3 dari nilai rata - rata uji uji kuat tekan pada beton normal pada umur rencana beton 28 hari dapat dilihat pada Gambar 6 .

\section{Persentase Penurunan Rata - Rata Nilai Uji Kuat Tekan Beton}

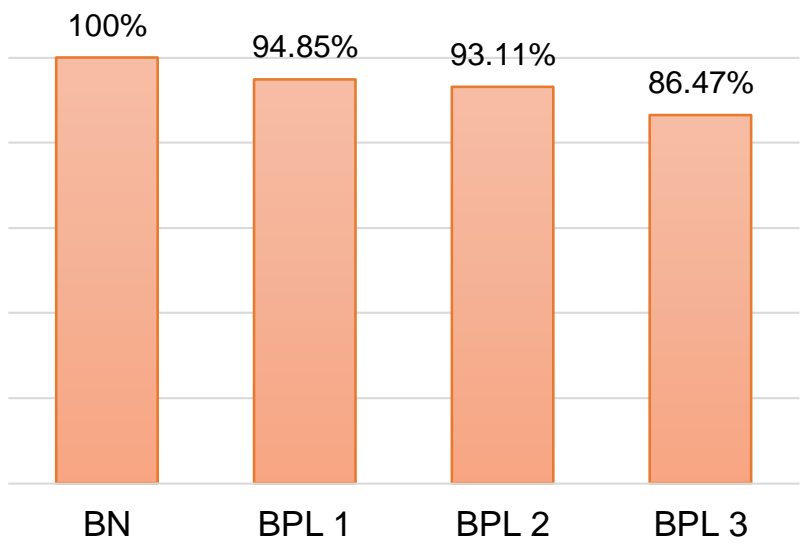

Gambar 6. Grafik Persentase Penurunan Rata - Rata Nilai Uji Kuat Tekan

Sumber: Analisa Penulis (2017)

Persentase ini merupakan capaian nilai kuat tekan sample beton dalam penelitian ini dengan perbandingan nilai kuat tekan beton normal pada umur beton 28 hari. Semakin banyak pemakaian limbah plastik sebagai agregat kasar berbanding dengan penurunan pada nilai kuat tekan yang di rencanakan. 
Nilai kuat tekan yang turun dapat terjadi karena agregat dari limbah plastik yang digunakan sebagai campuran agregat kasar mempunyai permukaan yang relatif lebih halus dibandingkan dengan agregat kasar yang berasal dari batu pecah, dimana limbah plastik yang digunakan sebagai agregat kasar dengan permukaan yang relatif lebih halus menyebabkan semakin lemahnya ikatan yang terjadi antara pasta

semen dengan agregat. Sehingga hasil uji kuat tekan pada beton dengan campuran limbah plastik polypropylene (PP) lebih kecil dibanding dengan hasil kuat tekan pada beton dengan campuran normal hal.

- Kuat Tarik

Nilai kuat tarik beton (direct tensile) diperoleh dengan membagi beban maksimum yang menyebabkan benda uji patah dengan luas bidang patahnya. Kekuatan tarik biasanya ditentukan dengan menggunakan percobaan pembebanan silinder, dimana silinder yang ukurannya sama dengan benda uji dalam percobaan kuat tekan diletakkan pada sisinya di atas mesin uji. Pengujian kuat tarik beton menggunakan benda uji silinder dengan ukuran $\varnothing 10 \mathrm{~cm}$ dan tinggi $20 \mathrm{~cm}$, pengujian dilakukan pada umur beton 3 hari, 7 Hari dan 28 hari. Dengan 4 sample komposisi campuran yang berbeda dan pada setiap sample dengan 3 benda uji dalam satu pengujian.

Perbandingan kuat tarik pada masing-masing rancang campuran beton dapat dilihat pada Tabel 5. nilai rata - rata kuat tarik beton gabungan dan perbandingan nilai kuat tarik pada masing - masing umur beton seperti pada umur beton 3 hari, 7 hari dan 28 hari dapat dilihat pada Gambar 7.

Tabel 5. Nilai Rata - Rata Kuat Tarik Beton Gabungan

\begin{tabular}{|c|c|c|c|c|}
\hline \multirow{2}{*}{$\begin{array}{c}\text { Umur } \\
\text { (Hari) }\end{array}$} & \multicolumn{4}{|c|}{ Kuat Tarik Beton (Mpa) } \\
\cline { 2 - 5 } & Normal & BPL 1 & BPL2 & BPL 3 \\
\hline 3 & 1,94 & 2,29 & 1,64 & 1,60 \\
\hline 7 & 2,62 & 2,57 & 2,39 & 1,84 \\
\hline 28 & 3,37 & 2,78 & 2,56 & 2,59 \\
\hline
\end{tabular}

Sumber: Analisa Penulis(2017)
Perbandingan Rata - Rata Kuat Tarik Beton (MPa)

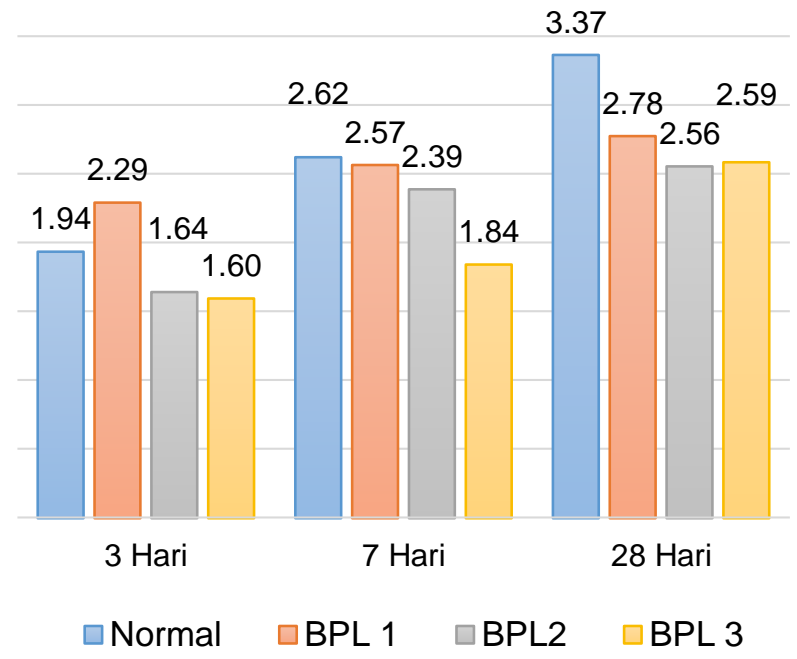

Gambar 7. Grafik Perbandingan Kuat Tarik Pada Masing-Masing Umur Beton

Sumber: Analisa Penulis,2017

Pengujian kuat tarik ini adalah untuk mengetahui ikatan antara agregat dan pasta semen. Dari gambar 4.5 dapat dilihat bahwa nilai kuat tarik beton pada umur 3 hari yang paling tinggi adalah beton BPL 1 sebesar 2,29 MPa selanjutnya beton normal sebesar 1,94 $\mathrm{MPa}$, nilai kuat tarik terkecil adalah BPL 3 sebesar 1,60 MPa.

Nilai kuat tarik beton pada umur 7 hari, beton normal memiliki nilai kekuatan tarik paling tinggi diantara beton lainnya yaitu sebesar 2,62 $\mathrm{MPa}$ diikuti oleh beton BPL 1 sebesar 2,57 MPa dan nilai kuat tarik terkecil beton pada umur 7 hari adalah beton BPL 3 dengan nilai kuat tarik sebesar 1,84 MPa. Nilai kuat tarik pada umur 28 hari biasanya memiliki kuat tarik $8 \%-15 \%$ dari kuat tekan beton normal (Pane, et al., 2015), nilai kuat tarik yang didapat pada campuran beton dengan menggunakan limbah plastik dengan kode BPL 1 sebesar 2,78 MPa, nilai kuat tarik ini lebih kecil dibandingan nilai kuat tarik beton normal sebesar 3,37 MPa namun lebih besar dari beton dengan campuran limbah plastik BPL 2 sebesar 2,56 MPa dan BPL 3 sebesar 2,59 MPa.

Besar persentase penurunan rata - rata uji kuat tekan beton BPL 1, BPL 2 dan BPL 3 dari nilai rata - rata uji uji kuat tekan pada beton normal pada umur rencana beton 28 hari dapat dilihat pada Gambar 8 . 
Persentase Penurunan Rata - Rata Nilai Uji Kuat Tarik Beton

$100 \%$

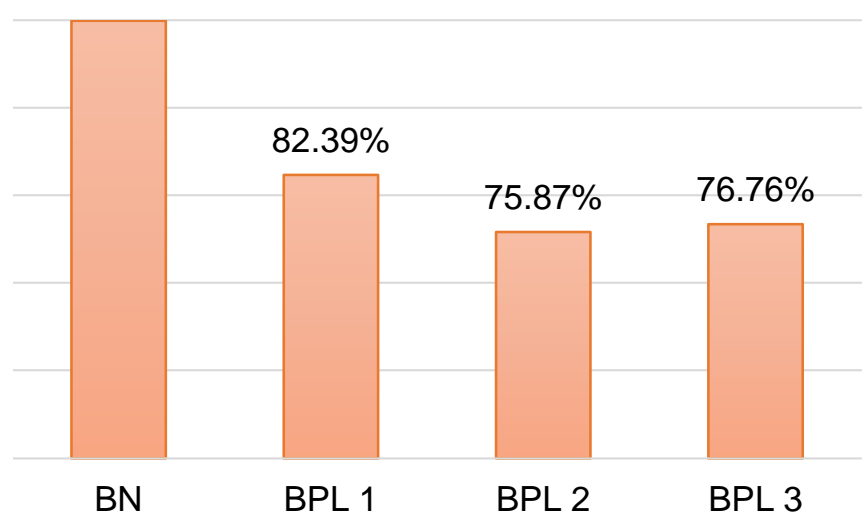

Gambar 8. Grafik Persentase Penurunan Rata Rata Nilai Uji Kuat Tarik

Sumber: Analisa Penulis (2017)

Penurunan nilai kuat tarik pada beton dengan campuran limbah plastik polypropylene 5\%, 10\% dan $15 \%$ berbanding lurus dengan penurunan nilai kuat tekan yang diperoleh dari pengujian kuat tekan beton dengan sampel yang sama. Nilai kuat tarik yang mengalami penurunan terjadi karena permukaan agregat limbah plastik yang digunakan sebagai campuran agregat kasar memiliki permukaan yang licin dan sulit mengikat pasta semen menjadi salah satu alasan lemahnya ikatan pada beton tersebut. Selain itu beton dengan campuran limbah plastik polypropylene (PP) sebagai agregat kasar bersifat lebih getas dibandingkan beton normal pada umumnya, sehingga kuat tarik beton lebih kecil dibandingkan dengan kuat tarik beton dengan campuran normal.

\section{KESIMPULAN DAN SARAN}

\section{Kesimpulan}

1. Kuat tekan beton dengan limbah plastik polypropylene (PP) dalam campuran agregat kasar mengalami penurunan sebesar $5,15 \%$ pada campuran limbah plastik 5\%, 6,89\% pada campuran limbah plastik $10 \%$ dan $13,53 \%$ pada campuran limbah plastik 15\%.

2. Kuat tarik beton dengan limbah plastik polypropylene (PP) dalam campuran agregat kasar mengalami penurunan sebesar $17,61 \%$ pada campuran limbah plastik 5\%, 24,13\% pada campuran limbah plastik $10 \%$ dan $23,24 \%$ pada campuran limbah plastik 15\%.

3. Penambahan persentase limbah plastik polypropylene (PP) pada campuran beton akan menurunkan nilai slump dimana nilai slump pada beton normal sebesar $12,5 \mathrm{~cm}$ sedangkan pada beton dengan campuran limbah plastik jenis polypropylene $5 \%$, $10 \%$ dan $15 \%$ sebagai campuran agregat kasar sebesar $8,5 \mathrm{~cm}, 6,5 \mathrm{~cm}$ dan $6 \mathrm{~cm}$.

\section{Saran}

Untuk penelitian lebih lanjut, pemanfaatan limbah plastik polypropylene (PP) sebagai campuran agregat kasar pada campuran beton Fc' 25 MPa sebaiknya :

1. Untuk meningkatkan nilai slump pada campuran beton dengan menggunakan limbah plastik polypropylene (PP) sebagai campuran agregat kasar, dapat menggunakan adi-mixture sebagai bahan pengencer.

2. Perlu dilakukan penelitian dengan menggunakan limbah plastik polypropylene (PP) sebagai campuran agregat kasar dengan ukuran yang lebih besar dan permukaan yang lebih kasar.

\section{UCAPAN TERIMA KASIH}

Dalam menyelesaikan Jurnal ini, penulis ingin mengucapkan terima kasih kepada:

1. Kedua orang tua penulis, yaitu alm. H. Bunyamin dan almh. Hj. Salbiah.

2. Bapak Ir. Akhmad Dofir, M.T, IPM selaku Ketua Program Studi Teknik Sipil Fakultas Teknik Universitas Pancasila.

3. Ibu Niken Warastuti, ST, MT selaku Sekretaris Program Studi Teknik Sipil Fakultas Teknik Universitas Pancasila.

4. Bapak Ir. Imam Hagni Puspito, M.T, IPM selaku pembimbing akademik di Program Studi Teknik Sipil Fakultas Teknik Universitas Pancasila

5. Bapak Dr. Ir. Jonbi, M.T, M.M, M.Si selaku pembimbing Tugas Akhir penulis.

6. Saudara Budi, Devi, Yanti dan Sandra selaku kakak dari penulis.

7. Keluarga Maman Suherman dan Ernawati yang selama ini membantu penulis.

\section{REFERENSI}

Charudatta, Thosar, \& M.Husain. (2017). Reuse of Plastic Waste as Replacement of Sand in Concrete. IJIRSET.

Felixon, K. (2011). Penelitian Terhadap Pengembangan Penggunaan Material Plastik (Polikarbonat) Pada Selubung Bangunan. Seminar Nasional AVoER ke-3.

Jambeck, J. R., Geyer, R., Wilcox, C., Siegler, T. R., Perryman, M., Andrady, A., . . . Law, K. L. (2015). Plastic Waste Inputs From Land Into The Ocean. sciencemag.org.

Nugraha, P., \& Antoni. (2007). Teknologi Beton "Dari Material, Pembuatan, Ke Beton Kinerja Tinggi". ANDI.

Pamudji, G., Intang, N., \& Rahman, A. N. (2008). Pengaruh Pemakaian Bahan Tambah Limbah Plastik Kemasan Air Mineral Terhadap Kuat Tekan Dan Kuat Tarik Belah Beton. 4. 
Pane, F. P., Tanudjaja, H., \& Windah, R. S. (2015).

Pengujian Kuat Tarik Lentur Beton Dengan

Variasi Kuat Tekan Beton. 3.

Ridwan, F. F., Subari, \& Yulius, E. (2014). Pengaruh Penggunaan Cacahan Gelas Plastik Polypropylene (PP) Terhadap Kuat Tekan Dan Tarik Beton. 2.

Tjokrodimuljo, K. (2007). Teknologi Beton. Yogyakarta: Biro Penerbit Teknik Sipil. 
Halaman ini sengaja dikosongkan 